\title{
Influence of Cutting Fluid on Abrasive - Free Ultrasonic Finishing of Aluminium Alloy
}

Jaroslava Svobodová ${ }^{1}$, Pavel Kraus ${ }^{1}$, Miroslav Müller ${ }^{2}$, Anatolii Lebedev $^{3}$, Alexander Yurov ${ }^{3}$, Pavel Lebedev ${ }^{3}$

${ }^{1}$ Faculty of production technology and management, Jan Evangelista Purkyně University in Ústí nad Labem. Czech Republic.E-mail: svobodova@fvtm.ujep.cz,kraus@fvtm.ujep.cz

${ }^{2}$ Faculty of Engineering, Czech University of Life Sciences Prague. Czech Republic. E-mail: muller@tf.czu.cz.

${ }^{4}$ Faculty of Agricultural Mechanization, Stavropol State Agrarian Mechanization, Russia. E-mail: lebedev.1962@mail.ru, AlexanderYurov@seznam.cz, zoya-lebedeva@mail.ru

The aim of the research was to compare a classical (turning) machining and an abrasive-free ultrasonic machining (bufo) at aluminium alloy. An ultrasonic set $I-4$ consisted of the ultrasonic generator, power output $630 \mathrm{~W}$ and working frequency $22 \mathrm{kHz} \pm 10 \%$, was used for the research. Three different cutting fluids containing nanoparticles were compared at the abrasive-free ultrasonic finishing. A rise of a hardness HVO.05 and HBW2.5/62.5 compared to the classical machining occurred at the application of the abrasive-free ultrasonic machining technology at the aluminium alloy by various cutting fluids containing nanoparticles. It is obvious from the results that a considerable fall of the surface roughness parameters $R a$ and $R z$ occurred at the application using the abrasivefree ultrasonic finishing.

Keywords: Hardness HV0.05, Hardness HBW2.5/62.5, Nano-powder, Surface Roughness, Ultrasound

\section{References}

[1] NOVÁK, M. (2012). Surfaces with high precision of roughness after grinding. In: Manufacturing technology. Vol. 12 , pp. $66-70$.

[2] NOVÁK, M. (2011). Surface quality of hardened steels after grinding. In: Manufacturing technology. Vol. 11, pp.55-59.

[3] HOLEŠOVSKÝ, F., NÁPRSTKOVÁ, N., NOVÁK, M. (2012). GICS for grinding process optimization. In: Manufacturing technology. Vol. 12, pp. 22-26.

[4] PA, P., S. (2009). Super finishing with ultrasonic and magnetic assistance in electrochemical micro-machining. In: Electrochimica Acta. Vol. 54 , pp. 6022-6027.

[5] MÜLLER, M., LEBEDEV, A., SVOBODOVÁ, J., NÁPRSTKOVÁ, N., LEBEDEV, P. (2014). Abrasive-free ultrasonic finishing of metals. In: Manufacturing Technology. Vol. 14, pp. 366-370.

[6] ČIERNA, H. ŤAVODOVÁ, M. (2013). Using the design of experiment method to evaluate quality of cuts after cutting aluminum alloy by AWJ. In: Manufacturing technology. Vol. 13, pp. 303-307.

[7] HRICOVA, J. (2014). Environmentally conscious manufacturing: the effect of metalworking fluid in high speed machining. In: Key engineering materials. Vol. 581, pp. 89-94.

[8] ŤAVODOVA, M. (2013). The surface quality of materials after cutting by abrasive water jet evaluated by selected methods. In: Manufacturing technology. Vol. 13, pp. 236-241.

[9] KROLCZYK, G., LEGUTKO, S. (2013). The machinability of duplex stainless steel-solutions in practice. In: Manufacturing technology. Vol. 13, pp. 473-478.

[10]HOLEŠOVSKÝ, F., NOVÁK, M., LATTER, M., VYSLOUZIL, T. (2013). Machining and its influence to surface quality of machine parts. In: Key Engineering Materials. Vol. 581. pp. 354-359.

[11]JÓZWIK, J., KURIC, I., SÁGA, M., LONKOWIC, P. (2014). Diagnostics of CNC machine tools in manufacturing process with laser interferometer technology. In: Manufacturing technology. Vol. 14, pp. 23-30.

[12] NOVÁK, M. (2013). New ways at the fine grinding. In: Key Engineering Materials. Vol. 581. pp. 255-260.

[13]VENKATESH, G., APURBBA KUMAR SHARMA, KUMAR, P. (2015). On ultrasonic assisted abrasive flow finishing of bevel gears. In: International Journal of Machine Tools and Manufacture. Vol. 89, pp. 29-38.

[14] SHAIKH, J.H., JAIN, N.K., VENKATESH, V.C. (2013). Precision finishing of Bevel Gears by Electrochemical Honing. In: Materials and Manufacturing Processes. Vol. 28, pp. 1117-1123.

[15] KOMARAIAH, M., REDDY, N. (1993). A study on the influence of workpiece properties in ultrasonic machining, In: International Journal of Machine Tools \& Manufacture. Vol. 33, pp. 495-505.

[16]CURODEAU, A., GUAY, J., RODRIGUE, D., BRAULT, L., GAGNE, D., BEAUDIOIN, L., P. (2008). Ultrasonic abrasive $\mu$-machining with thermoplastic tooling. In: International Journal of Machine Tools \& Manufacture. Vol. 48, pp. 1553-1561.

[17]LEGUTKO, S., KROLCZYK, G., KROLCZYK, G. (2014). Quality evaluation of surface layer in highly accurate manufacturing. In: Manufacturing technology. Vol. 14, pp. 50-56. 